Article

\title{
Mosquitocidal and Oviposition Repellent Activities of the Extracts of Seaweed Bryopsis pennata on Aedes aegypti and Aedes albopictus
}

\section{Ke-Xin Yu ${ }^{1}$, Ching-Lee Wong ${ }^{2}$, Rohani Ahmad ${ }^{3}$ and Ibrahim Jantan ${ }^{1, *}$}

1 Drug and Herbal Research Centre, Faculty of Pharmacy, Universiti Kebangsaan Malaysia, 50300 Kuala Lumpur, Malaysia; E-Mail: yukxxin@gmail.com

2 School of Biosciences, Taylor's University, Taylor's Lakeside Campus, Subang Jaya, 47500 Selangor, Malaysia; E-Mail: chinglee.wong@taylors.edu.my

3 Medical Entomology Unit, Infectious Disease Research Centre, Institute for Medical Research, 50588 Kuala Lumpur, Malaysia; E-Mail: rohania@imr.gov.my

* Author to whom correspondence should be addressed; E-Mail: profibj@gmail.com; Tel.: +60-1-6288-6445; Fax: +60-3-2698-3271.

Academic Editor: Derek J. McPhee

Received: 16 June 2015 / Accepted: 29 July 2015 / Published: 4 August 2015

\begin{abstract}
The ever-increasing threat from infectious diseases and the development of insecticide resistance in mosquito populations drive the global search for new natural insecticides. The aims of this study were to evaluate the mosquitocidal activity of the extracts of seaweed Bryopsis pennata against dengue vectors Aedes aegypti and Aedes albopictus, and determine the seaweed's toxic effect on brine shrimp nauplii (as a non-target organism). In addition, the chemical compositions of the active larvicidal extract and fraction were analyzed by using liquid chromatography-mass spectrometry (LC-MS). Chloroform extract exhibited strong ovicidal activity (with LC 50 values of 229.3 and $250.5 \mu \mathrm{g} / \mathrm{mL}$ ) and larvicidal activity against Ae. aegypti and Ae. albopictus. The larvicidal potential of chloroform extract was further ascertained when its $\mathrm{A} 7$ fraction exhibited strong toxic effect against Ae. aegypti $\left(\mathrm{LC}_{50}=4.7 \mu \mathrm{g} / \mathrm{mL}\right)$ and Ae. albopictus ( $\left.\mathrm{LC}_{50}=5.3 \mu \mathrm{g} / \mathrm{mL}\right)$. LC-MS analysis of the chloroform extract gave a tentative identification of 13 compounds; Bis-(3-oxoundecyl) tetrasulfide was identified as the major compound in A7 fraction. Methanol extract showed strong repellent effect against female oviposition, along with weak adulticidal activity against mosquito and weak toxicity against brine shrimp nauplii. The mosquitocidal results of $B$. pennata suggest further investigation for the development of effective insecticide.
\end{abstract}


Keywords: dengue vector; ovicidal; larvicidal; insecticide; bis-(3-oxoundecyl) tetrasulfide

\section{Introduction}

Dengue fever and dengue hemorrhagic fever cause 50 to 100 million infection cases, with about 2.5\% of those affected dying every year globally. Prior to 1970, only nine countries reported dengue cases, but presently at least 100 countries across Asia, Africa, America, Pacific and Caribbean islands claim to have endemic dengue [1]. Furthermore, earlier studies indicated that epidemic dengue occurs periodically every three to five years and most likely an increase in the magnitude and severity of cases with each new epidemic [2]. Besides the increasing number of infection cases and deaths, dengue fever also poses a growing burden to the economics of endemic and newly affected countries. For example, dengue infection in the Americas was estimated to cost US \$2.1 billion per year [3]. Furthermore, dengue hemorrhagic fever is listed among the 10 leading causes of hospitalization in at least eight Asian countries [4]. Dengue fever and dengue hemorrhagic fever are mainly transmitted by mosquitoes, namely Aedes aegypti and Aedes albopictus in tropical countries. As female adults of Ae. aegypti and Ae. albopictus are anthropophilic, humans are at high risk of being targeted as hosts by the blood meal-seeking insect. Aedes mosquitoes become infected with dengue virus through feeding on infected humans and once the mosquitoes are infected, they remain infected for life. Furthermore, dengue virus also remains in the mosquito population by transovarial transmission [5].

There has been a heavy dependence on synthetic chemical insecticides for mosquito control programs since the discovery of chemical insecticides. The wide acceptance of chemical insecticides is due to their rapid effectiveness and convenience. However, prolonged usage of synthetic chemicals leads to undesirable effects, such as development of insecticide resistance in the vector population, environmental pollution and accidental poisoning of humans and non-target organisms [6]. Consequently, the search for alternative approaches in mosquito control has become crucial.

Bryopsis pennata, a seaweed species under the family of Bryopsidaceae, is widely distributed in tropical and temperate marine waters. B. pennata has green thallus with irregularly branched main axis, and forms tufts on rocks in the intertidal habitat or coral reefs [7]. This green seaweed has been found to exhibit antimicrobial activity towards pathogenic bacteria, fungi [8] and marine protists [9]. In addition, B. pennata also induces inotropic effect towards ventricular muscle strips of toad and positive chronotropic action towards isolated right atria of rat [10]. On top of that, the bioactive constituents of Bryopsis species have also been studied in various assays. For example, Kahalalides F, a polypeptide isolated from sacoglossan mollusk Elysia rufescens and its diet-green seaweed Bryopsis species [11], has been introduced into clinical phase trials as an anticancer agent against prostate cancer [12]. Biju et al. [13] reported that Bryopsis plumosa had antifeedant properties against larvae of moth Hyblaea puera and was able to reduce the protein and fat content of the treated larvae.

Apart from having unique bioactive secondary metabolites with medicinal properties [14], seaweeds have been reported to have mosquitocidal properties [15-17]. Recently, the larvicidal activity of extracts and compounds of 30 seaweed species was described in the review of Yu et al. [18]. The few evaluations of mosquitocidal activities of seaweeds published provide limited information on the bio-efficacy of 
seaweed based insecticide, as compared to the usage of seaweeds in food and pharmaceutical applications. The findings of mosquitocidal properties of B. pennata are useful to the researchers of drug, insecticide and mosquito control programmes, as well as national governments and policy makers to prioritize their efforts. To help address this need, the present study evaluated the mosquitocidal potency of $B$. pennata against two dengue vectors, Ae. aegypti and Ae. Albopictus, and the toxic effect of this seaweed against non-target organism-nauplii of the brine shrimp Artemia salina, and characterized the seaweed by using liquid chromatography-mass spectrometry (LC-MS).

\section{Results and Discussion}

\subsection{Seaweed Extraction}

The dried seaweed yielded $17.16 \% \pm 1.60 \%(w / w)$ of methanol extract. Liquid-liquid partition of methanol extract (12.0 g) gave to $5.8 \mathrm{~g}$ of hexane extract, $3.4 \mathrm{~g}$ of chloroform extract and $1.4 \mathrm{~g}$ of aqueous extract. VLC of chloroform extract yielded 8 fractions, namely A1 (0.1 g), A2 (0.6 g), A3 (0.3 g), A4 (0.2 g), A5 (0.5 g), A6 (0.4 g), A7 (0.3 g), and A8 (0.6 g).

\subsection{Mosquito Ovicidal Assay}

The ovicidal assay of the dengue vectors Ae. aegypti and Ae. albopictus at $24 \mathrm{~h}$ post-treatment was tested with different concentrations of $B$. pennata extract, and the results are listed in Table 1 . The chloroform extract of $B$. pennata was found to be the strongest ovicidal agent against Ae. aegypti and Ae. albopictus (exhibiting approximately 0.3 to 3.1 -fold stronger activity than other extracts).

Table 1. Ovicidal activity of Bryopsis pennata extracts against Aedes aegypti and Aedes albopictus.

\begin{tabular}{ccccc}
\hline Mosquito & Extract & $\left.\mathbf{L C}_{\mathbf{5 0}}(\boldsymbol{\mu} \mathbf{g} / \mathbf{m L}) \mathbf{( 9 5 \%} \mathbf{C L}\right)$ & Slope $( \pm \mathbf{S E})$ & $\boldsymbol{X}^{\mathbf{2}}$ \\
\hline & $n$-Hexane & $624.90(579.10-674.40)$ & $1.05(0.03)$ & 0.99 \\
& Chloroform * & $229.30(167.50-313.90)$ & $2.53(0.61)$ & 0.93 \\
Aedes aegypti & Methanol & $315.30(252.30-394.20)$ & $1.93(0.35)$ & 0.94 \\
& Aqueous & $939.80(747.70-1181.00)$ & $1.47(0.11)$ & 0.99 \\
& Abate ${ }^{\circledR} 1.1 \mathrm{G}$ & $0.02(0.01-0.03)$ & $2.24(0.47)$ & 0.98 \\
\hline & $n$-Hexane & $542.20(460.30-638.80)$ & $1.85(0.20)$ & 0.98 \\
& Chloroform * & $250.50(190.10-330.20)$ & $2.85(0.69)$ & 0.94 \\
Aedes albopictus & Methanol & $396.60(319.80-491.90)$ & $1.76(0.30)$ & 0.95 \\
& Aqueous & $691.60(440.20-1087.00)$ & $1.14(0.20)$ & 0.70 \\
& Abate ${ }^{\circledR} 1.1 \mathrm{G}$ & $0.45(0.21-0.63)$ & $1.72(0.26)$ & 0.78 \\
\hline
\end{tabular}

$\mathrm{LC}_{50}$, lethal concentration that kills $50 \%$ of the exposed eggs; $95 \% \mathrm{CL}, 95 \%$ confidence limits; $X^{2}$, chi-square value; * Extract with the strongest ovicidal effect.

\subsection{Mosquito Larvicidal Assay}

The larvicidal activity of B. pennata towards larvae of Ae. aegypti and Ae. albopictus at $24 \mathrm{~h}$ post-treatment was studied. The data clearly revealed that only chloroform extract had $\mathrm{LC}_{50}$ values below the concentration of $100 \mu \mathrm{g} / \mathrm{mL}$ (Table 2 ). 
Table 2. Larvicidal activity of Bryopsis pennata extracts against Aedes aegypti and Aedes albopictus.

\begin{tabular}{ccccc}
\hline Mosquito & Extract & $\left.\mathbf{L C}_{\mathbf{5 0}}(\boldsymbol{\mu g} \mathbf{m} \mathbf{m L}) \mathbf{( 9 5 \%} \mathbf{C L}\right)$ & Slope $( \pm \mathbf{S E})$ & $\boldsymbol{X}^{\mathbf{2}}$ \\
\hline & $n$-Hexane & $912.86(821.04-1095.18)$ & $5.25(0.85)$ & 1.12 \\
& Chloroform * & $92.72(82.40-102.85)$ & $3.01(0.31)$ & 3.14 \\
Aedes aegypti & Methanol & $156.97(133.54-179.46)$ & $2.57(0.25)$ & 1.47 \\
& Aqueous & $591.77(528.19-692.70)$ & $3.78(0.49)$ & 0.21 \\
& Abate ${ }^{\circledR} 1.1 \mathrm{G}$ & $0.07(0.06-0.08)$ & $3.21(0.21)$ & 0.90 \\
\hline & $n$-Hexane & $1209.50(1123.50-1318.65)$ & $3.15(0.68)$ & 1.83 \\
& Chloroform * & $99.85(88.68-111.27)$ & $2.81(0.31)$ & 0.65 \\
Aedes albopictus & Methanol & $177.50(156.41-198.68)$ & $3.05(0.27)$ & 4.02 \\
& Aqueous & $692.45(657.01-735.71)$ & $7.39(0.84)$ & 0.70 \\
& Abate $^{\circledR} 1.1 \mathrm{G}$ & $0.93(0.82-1.07)$ & $2.85(0.34)$ & 1.72 \\
\hline
\end{tabular}

$\mathrm{LC}_{50}$, lethal concentration that kills $50 \%$ of the exposed larvae; $95 \% \mathrm{CL}, 95 \%$ confidence limits; $X^{2}$, chi-square value; * Extract with the strongest larvicidal effect.

As the most active extract of $B$. pennata in larvicidal assay, the chloroform extract was fractioned into 8 fractions and these fractions were subjected to mosquito larvicidal assay. Out of them, A7 was the strongest larvicidal fraction with approximately 5 to 68 -fold stronger activity than others (Table 3 ).

Table 3. Larvicidal activity of the fractions derived from chloroform extract of Bryopsis pennata against Aedes aegypti and Aedes albopictus.

\begin{tabular}{ccccc}
\hline Mosquito & Fraction & $\mathbf{L C}_{\mathbf{5 0}}(\boldsymbol{\mu} \mathbf{g} / \mathbf{m L})(\mathbf{9 5 \%} \mathbf{C L})$ & Slope $( \pm$ SE) & $\boldsymbol{X}^{\mathbf{2}}$ \\
\hline & $\mathrm{A} 1$ & $324.50(308.55-356.20)$ & $2.68(0.75)$ & 0.96 \\
& $\mathrm{~A} 2$ & $226.10(201.50-251.35)$ & $2.45(0.60)$ & 0.95 \\
& $\mathrm{~A} 3$ & $189.33(160.30-210.30)$ & $2.86(0.47)$ & 0.94 \\
Aedes aegypti & $\mathrm{A} 4$ & $209.45(192.34-225.19)$ & $2.13(0.93)$ & 0.91 \\
& $\mathrm{~A} 5$ & $146.43(123.59-167.98)$ & $2.21(0.35)$ & 0.96 \\
& $\mathrm{~A} 6$ & $26.81(16.53-43.47)$ & $1.18(0.48)$ & 0.48 \\
& $\mathrm{~A} 7 *$ & $4.65(3.08-7.01)$ & $1.29(0.55)$ & 0.68 \\
& $\mathrm{~A} 8$ & $254.29(271.50-226.30)$ & $2.11(0.67)$ & 0.96 \\
& Abate ${ }^{\circledR} 1.1 \mathrm{G}$ & $0.07(0.06-0.08)$ & $3.21(0.21)$ & 0.90 \\
\hline & $\mathrm{A} 1$ & $256(239.15-281.50)$ & $2.11(0.78)$ & 0.90 \\
& $\mathrm{~A} 2$ & $227.80(201.45-256.87)$ & $2.62(0.82)$ & 0.98 \\
Aedes albopictus & $\mathrm{A} 3$ & $181.55(165.39-201.45)$ & $1.88(0.62)$ & 0.96 \\
& $\mathrm{~A} 4$ & $193.45(213.90-178.32)$ & $1.89(0.70)$ & 0.95 \\
& $\mathrm{~A} 5$ & $128.40(108.75-152.50)$ & $1.73(0.68)$ & 0.98 \\
& $\mathrm{~A} 6$ & $38.78(33.89-44.37)$ & $3.98(0.75)$ & 0.88 \\
& $\mathrm{~A} 7 *$ & $5.32(3.95-7.16)$ & $1.87(0.62)$ & 0.81 \\
& $\mathrm{~A} 8$ & $278.90(291.15-256.21)$ & $1.99(0.74)$ & 0.90 \\
& Abate ${ }^{\circledR} 1.1 \mathrm{G}$ & $0.93(0.82-1.07)$ & $2.85(0.34)$ & 1.72 \\
\hline
\end{tabular}

$\mathrm{LC}_{50}$, lethal concentration that kills $50 \%$ of the exposed larvae; $95 \% \mathrm{CL}, 95 \%$ confidence limits; $X^{2}$, chi-square value; * Fraction with the strongest larvicidal effect. 
Larvae treated with chloroform extract of B. pennata were observed to exhibit abnormal behaviour. These mosquito larvae showed signs of unnatural restlessness, wriggling movement and frequent sinking followed by floating, after $1-5 \mathrm{~h}$ of treatment. Such behaviour persisted until the larvae became sluggish, paralyzed and eventually sank to the bottom of the container. Mortality of the larvae was found to be on the rise from 5-20 h. Similar observations were noted for all larvae treated with different extracts except for the time and duration of exhibiting the intoxicated symptoms.

In addition, larvae under the treatment of chloroform extract of $B$. pennata were observed to have darkened body segments and shrunken anal papillae as compared to the normal larvae. Further investigation under the electron microscope revealed that the treated larvae had spiracular apparatus with damaged inner structures (Figure 1). Similar observations were noted for all larvae treated with different extracts.
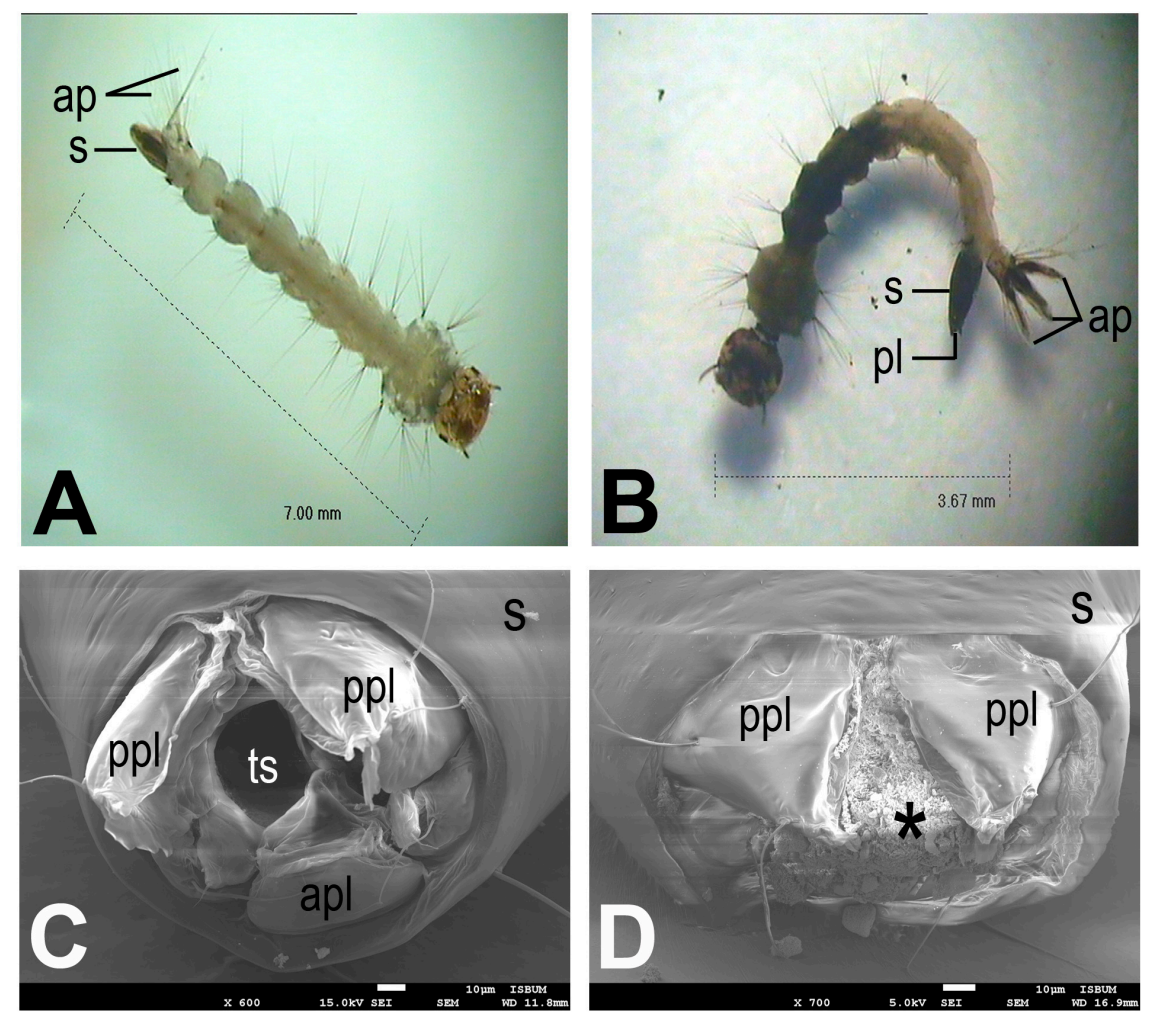

Figure 1. Photographs of Aedes albopictus larvae: (A) larva of negative control; (B) larva treated with chloroform extract of Bryopsis pennata showing darkened body parts and anal papillae; (C) larva of negative control showing intact spiracular apparatus; (D) larva treated with chloroform extract of $B$. pennata showing spiracular apparatus with damaged inner structures (*). ap, anal papillae; apl, anterior perispiracular lobe; pl, perispiracular lobes; ppl, posterior perispiracular lobe; s, siphon; ts, terminal spiracle.

\subsection{Mosquito Adulticidal Assay}

The adulticidal activity of extracts of $B$. pennata against female mosquitoes at $24 \mathrm{~h}$ post-treatment is presented in Table 4. The chloroform extract was found to be the most effective adulticidal agent. No mortality was observed in negative control. The female adults treated with extract showed unusual restless movement and hardly remained still on the surface of the holding tube after being exposed to 
the treatment at high concentration. After 10-20 h of treatment, the female adults were increasingly found to wag, became paralyzed, lay at the bottom of the holding tube and then died.

Table 4. Adulticidal activity of Bryopsis pennata extracts against female adult of Aedes aegypti and Aedes albopictus.

\begin{tabular}{ccccc}
\hline Mosquito & Extract & $\left.\mathbf{L C}_{\mathbf{5 0}}\left(\mathbf{m g} / \mathbf{c m}^{\mathbf{2}}\right) \mathbf{( 9 5 \%} \mathbf{C L}\right)$ & Slope $( \pm \mathbf{S E})$ & $\boldsymbol{X}^{\mathbf{2}}$ \\
\hline & Hexane & $233.55(200.34-294.34)$ & $2.34(0.90)$ & 1.73 \\
& Chloroform * & $73.49(64.89-85.34)$ & $3.72(0.81)$ & 2.35 \\
Aedes aegypti & Methanol & $86.48(76.76-97.42)$ & $1.14(0.05)$ & 0.99 \\
& Aqueous & $523.82(452.56-559.23)$ & $1.34(0.72)$ & 1.45 \\
& Malathion & $0.01(0.005-0.02)$ & $1.785(0.04)$ & 0.96 \\
\hline & Hexane & $434.32(380.45-480.21)$ & $3.45(0.82)$ & 1.93 \\
& Chloroform * & $100.32(83.78-163.48)$ & $1.39(1.56)$ & 1.34 \\
Aedes albopictus & Methanol & $156.34(150.10-162.80)$ & $1.41(0.27)$ & 0.99 \\
& Aqueous & $689.39(602.34-723.43)$ & $2.34(2.36)$ & 2.12 \\
& Malathion & $0.015(0.009-0.021)$ & $1.423(0.03)$ & 0.98 \\
\hline
\end{tabular}

$\mathrm{LC}_{50}$, lethal concentration that kills $50 \%$ of the exposed adults; $95 \% \mathrm{CL}, 95 \%$ confidence limits; $X^{2}$, chi-square value; * Extract with the strongest adulticidal effect.

\subsection{Mosquito Oviposition Assay}

The oviposition activity of B. pennata against female adults of Ae. aegypti and Ae. albopictus (Table 5) proved its efficacy as oviposition repellent. The most effective repellency against mosquito gravid females was exhibited by methanol extract. Repellency of $B$. pennata increased with the increase of concentration. All extracts at five concentrations tested were observed to repel mosquitoes from oviposition, except for the aqueous extract at 50 and $100 \mu \mathrm{g} / \mathrm{mL}$, hexane extract at $50 \mu \mathrm{g} / \mathrm{mL}$ and chloroform extract at $50 \mu \mathrm{g} / \mathrm{mL}$, which exhibited no effect on the oviposition activity.

Table 5. Oviposition activity of Bryopsis pennata extracts against Aedes aegypti and Aedes albopictus.

\begin{tabular}{|c|c|c|c|c|c|c|}
\hline \multirow{3}{*}{ Extract } & \multirow{3}{*}{ Con. $(\mu g / m L)$} & \multirow{3}{*}{ OAI $(\mathbf{A} / \mathbf{N} / \mathbf{R})^{1}$} & \multicolumn{4}{|c|}{ Effective Repellency (ER) } \\
\hline & & & \multirow{2}{*}{$\begin{array}{c}\text { Percentage } \\
(\text { Mean } \pm \text { SE })^{2}\end{array}$} & \multicolumn{3}{|c|}{ Probit Analysis } \\
\hline & & & & $\mathrm{RC}_{50}(\mu \mathrm{g} / \mathrm{mL})(95 \% \mathrm{CL})$ & Slope $( \pm$ SE) & $X^{2}$ \\
\hline \multicolumn{7}{|c|}{ Aedes aegypti } \\
\hline \multirow{5}{*}{ Hexane } & 50 & $-0.28(\mathrm{~N})$ & $42.40 \pm 5.30^{\mathrm{a}}$ & \multirow{5}{*}{$60.78(48.38-76.36)$} & \multirow{5}{*}{$1.73(0.31)$} & \multirow{5}{*}{0.83} \\
\hline & 100 & $-0.53(\mathrm{R})$ & $69.54 \pm 7.32^{\mathrm{a}}$ & & & \\
\hline & 200 & $-0.78(\mathrm{R})$ & $87.63 \pm 8.32^{\mathrm{a}}$ & & & \\
\hline & 300 & $-0.90(\mathrm{R})$ & $94.98 \pm 5.42^{\mathrm{a}}$ & & & \\
\hline & 400 & $-0.98(\mathrm{R})$ & $98.92 \pm 4.76^{\mathrm{a}}$ & & & \\
\hline \multirow{5}{*}{ Chloroform } & 50 & $-0.29(\mathrm{~N})$ & $46.55 \pm 4.20^{b}$ & \multirow{5}{*}{$54.58(43.41-68.63)$} & \multirow{5}{*}{$1.85(0.36)$} & \multirow{5}{*}{0.82} \\
\hline & 100 & $-0.59(\mathrm{R})$ & $74.17 \pm 3.43^{b}$ & & & \\
\hline & 200 & $-0.85(\mathrm{R})$ & $91.94 \pm 9.60^{b}$ & & & \\
\hline & 300 & $-0.93(\mathrm{R})$ & $96.23 \pm 6.89^{a, b}$ & & & \\
\hline & 400 & $-1.00(\mathrm{R})$ & $100.00 \pm 5.23^{\mathrm{a}}$ & & & \\
\hline
\end{tabular}


Table 5. Cont.

\begin{tabular}{|c|c|c|c|c|c|c|}
\hline \multirow{3}{*}{ Extract } & \multirow{3}{*}{ Con. $(\mu \mathrm{g} / \mathrm{mL})$} & \multirow{3}{*}{ OAI $(\mathbf{A} / \mathbf{N} / \mathbf{R})^{1}$} & \multicolumn{4}{|c|}{ Effective Repellency (ER) } \\
\hline & & & \multirow{2}{*}{$\begin{array}{c}\text { Percentage } \\
(\text { Mean } \pm \text { SE })^{2}\end{array}$} & \multicolumn{3}{|c|}{ Probit Analysis } \\
\hline & & & & $\mathrm{RC}_{50}(\mu \mathrm{g} / \mathrm{mL})(95 \% \mathrm{CL})$ & Slope $( \pm$ SE) & $X^{2}$ \\
\hline \multirow{5}{*}{ Methanol * } & 50 & $-0.42(\mathrm{R})$ & $56.40 \pm 6.51^{\mathrm{c}}$ & \multirow{5}{*}{$44.36(35.21-55.85)$} & \multirow{5}{*}{$2.22(0.55)$} & \multirow{5}{*}{0.80} \\
\hline & 100 & $-0.77(\mathrm{R})$ & $86.75 \pm 7.91^{\mathrm{c}}$ & & & \\
\hline & 200 & $-0.90(\mathrm{R})$ & $94.62 \pm 6.71^{b}$ & & & \\
\hline & 300 & $-0.98(\mathrm{R})$ & $98.74 \pm 2.58^{b}$ & & & \\
\hline & 400 & $-1.00(\mathrm{R})$ & $100.00 \pm 2.50^{\mathrm{a}}$ & & & \\
\hline \multirow{5}{*}{ Aqueous } & 50 & $-0.19(\mathrm{~N})$ & $29.86 \pm 6.82^{\mathrm{d}}$ & \multirow{5}{*}{$106.30(84.86-133.10)$} & \multirow{5}{*}{$1.58(0.25)$} & \multirow{5}{*}{0.85} \\
\hline & 100 & $-0.26(\mathrm{~N})$ & $41.06 \pm 4.90^{\mathrm{d}}$ & & & \\
\hline & 200 & $-0.55(\mathrm{R})$ & $70.97 \pm 9.37^{\mathrm{c}}$ & & & \\
\hline & 300 & $-0.76(\mathrm{R})$ & $86.19 \pm 5.92^{c}$ & & & \\
\hline & 400 & $-0.90(\mathrm{R})$ & $94.98 \pm 2.34^{b}$ & & & \\
\hline \multicolumn{7}{|c|}{ Aedes albopictus } \\
\hline \multirow{5}{*}{ Hexane } & 50 & $-0.20(\mathrm{~N})$ & $32.49 \pm 5.45^{\mathrm{a}}$ & \multirow{5}{*}{$70.67(58.22-85.77)$} & \multirow{5}{*}{$1.79(0.27)$} & \multirow{5}{*}{0.87} \\
\hline & 100 & $-0.54(\mathrm{R})$ & $70.50 \pm 5.39^{a}$ & & & \\
\hline & 200 & $-0.67(\mathrm{R})$ & $79.88 \pm 7.31^{\mathrm{a}}$ & & & \\
\hline & 300 & $-0.88(\mathrm{R})$ & $93.44 \pm 4.90^{\text {a }}$ & & & \\
\hline & 400 & $-0.95(\mathrm{R})$ & $97.70 \pm 2.33^{\mathrm{a}}$ & & & \\
\hline \multirow{5}{*}{ Chloroform } & 50 & $-0.19(\mathrm{~N})$ & $30.80 \pm 5.10^{\mathrm{a}}$ & \multirow{5}{*}{$68.91(58.06-81.80)$} & \multirow{5}{*}{$2.14(0.35)$} & \multirow{5}{*}{0.88} \\
\hline & 100 & $-0.59(\mathrm{R})$ & $74.10 \pm 3.43^{\mathrm{a}}$ & & & \\
\hline & 200 & $-0.76(\mathrm{R})$ & $86.39 \pm 8.64^{\mathrm{a}, \mathrm{b}}$ & & & \\
\hline & 300 & $-0.85(\mathrm{R})$ & $91.80 \pm 3.51^{\mathrm{a}}$ & & & \\
\hline & 400 & $-0.97(\mathrm{R})$ & $98.62 \pm 5.12^{a}$ & & & \\
\hline \multirow{5}{*}{ Methanol * } & 50 & $-0.29(\mathrm{~N})$ & $47.50 \pm 6.30^{\mathrm{a}}$ & \multirow{5}{*}{$51.60(46.31-57.50)$} & \multirow{5}{*}{$2.81(0.46)$} & \multirow{5}{*}{0.91} \\
\hline & 100 & $-0.78(\mathrm{R})$ & $87.77 \pm 4.92^{b}$ & & & \\
\hline & 200 & $-0.90(\mathrm{R})$ & $94.67 \pm 2.36^{b}$ & & & \\
\hline & 300 & $-0.98(\mathrm{R})$ & $98.91 \pm 2.44^{b}$ & & & \\
\hline & 400 & $-1.00(\mathrm{R})$ & $100.00 \pm 2.56^{\mathrm{a}}$ & & & \\
\hline \multirow{5}{*}{ Aqueous } & 50 & $-0.08(\mathrm{~N})$ & $17.80 \pm 4.58^{\mathrm{a}}$ & \multirow{5}{*}{$154.20(129.70-183.50)$} & & \\
\hline & 100 & $-0.20(\mathrm{~N})$ & $33.09 \pm 2.90^{\mathrm{c}}$ & & & \\
\hline & 200 & $-0.37(\mathrm{R})$ & $53.85 \pm 8.65^{\mathrm{c}}$ & & $1.64(0.21)$ & 0.89 \\
\hline & 300 & $-0.61(\mathrm{R})$ & $75.41 \pm 3.74^{\mathrm{c}}$ & & & \\
\hline & 400 & $-0.81(\mathrm{R})$ & $89.40 \pm 4.35^{b}$ & & & \\
\hline
\end{tabular}

${ }^{1}$ A, Attractant; N, No effect; R, Repellent; ${ }^{2}$ Values followed by different letters within the same column of the same concentration are significantly different $(p<0.05) ; *$ Extract with the strongest oviposition repellent effect. $\mathrm{RC}_{50}$, concentration that causes $50 \%$ of the oviposition repellent activity; $95 \% \mathrm{CL}, 95 \%$ confidence limits; $X^{2}$, chi-square value.

\subsection{Brine Shrimp Toxicity Assay}

Table 6 shows that all $B$. pennata extracts exhibited very mild toxicity against the nauplii of Artemia salina ( $\mathrm{LC}_{50}$ values above $500 \mu \mathrm{g} / \mathrm{mL}$ ). Hexane extract of $B$. pennata was the most potent extract for the brine shrimp. It was observed that most nauplii became paralyzed and then died lying at the bottom of container, after $5-10 \mathrm{~h}$ of high-concentration treatment. 
Table 6. Toxic effect of Bryopsis pennata extracts against nauplii of brine shrimp Artemia salina.

\begin{tabular}{cccc}
\hline Extract & $\mathbf{L C}_{\mathbf{5 0}}(\boldsymbol{\mu g} / \mathbf{m L})(\mathbf{9 5 \%} \mathbf{C L})$ & Slope $( \pm \mathbf{S E}) \boldsymbol{X}^{\mathbf{2}}$ \\
\hline Methanol & $1135.98(901.50-1288.30)$ & $2.98(0.83) 0.99$ \\
Hexane * & $591.82(535.70-655.29)$ & $0.22(0.01) 0.98$ \\
Chloroform & $911.50(817.12-1055.17)$ & $0.19(0.01) 0.98$ \\
Aqueous & $1238.23(1198.50-1381.33)$ & $2.12(0.71) 0.91$ \\
Potassium dichromate & $27.15(25.07-29.41)$ & $1.21(0.06)$ & 0.99 \\
\hline
\end{tabular}

$\mathrm{LC}_{50}$, lethal concentration that kills $50 \%$ of the exposed nauplii; $95 \% \mathrm{CL}, 95 \%$ confidence limits; $X^{2}$, chi-square value; * Extract with the strongest lethal effect.

\subsection{Liquid Chromatography-Mass Spectrometry Analysis}

Since chloroform extract and A7 fraction of B. pennata exhibited strong larvicidal activity, their chemical constituents were investigated and analyzed by using liquid chromatography-mass spectrometry (LC-MS). The LC-MS profile of the chloroform extract exhibited 17 peaks that were resolved in $36 \mathrm{~min}$ (Figure 2A), while the LC-MS profile of A7 fraction showed two main peaks (i and ii) (Figure 2B).

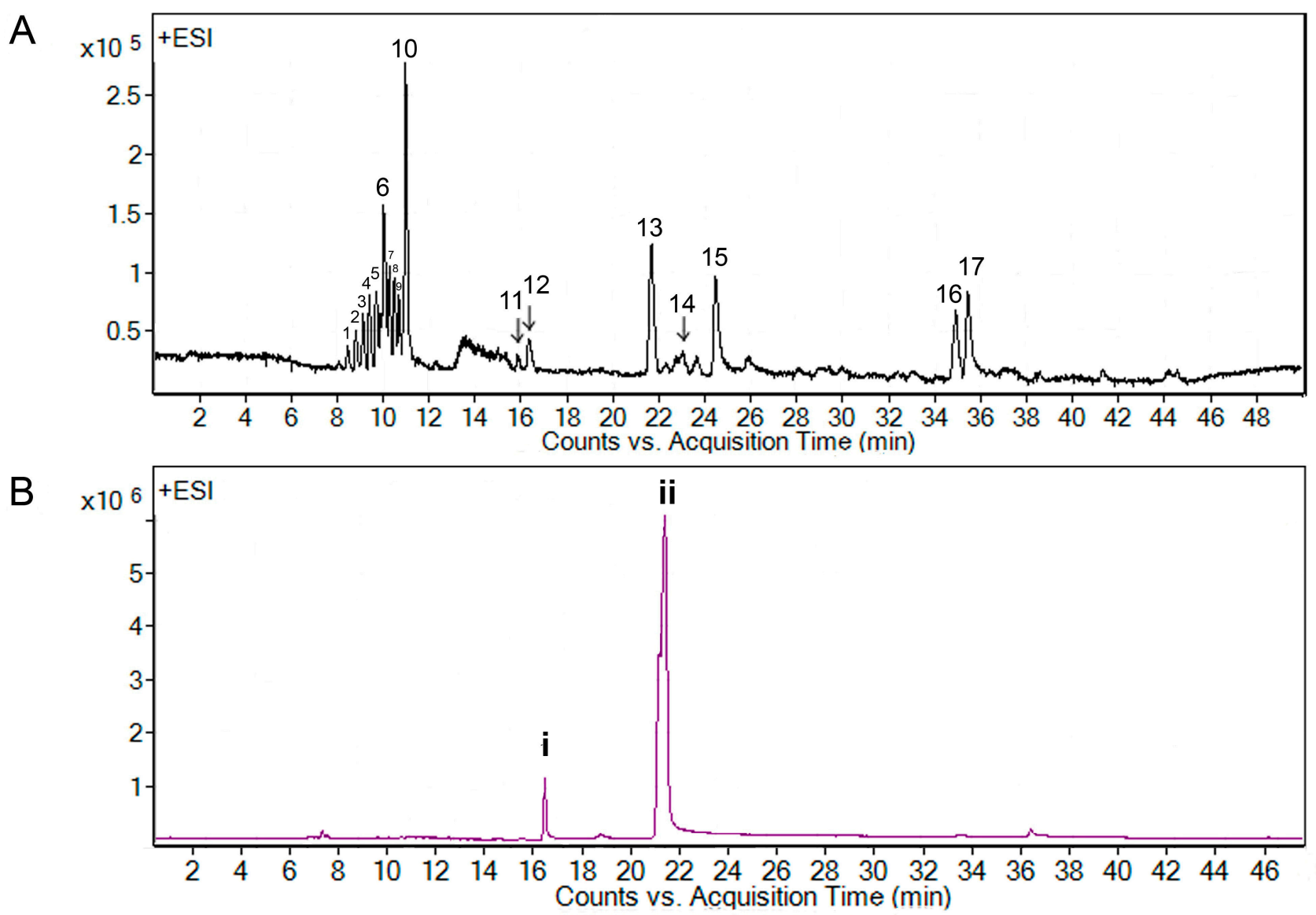

Figure 2. LC-MS extracted ion chromatogram of Bryopsis pennata, (A) chloroform extract and (B) A7 fraction. 
All the main peaks belonging to various compounds were tentatively assigned by comparing the data acquired by Mass Hunter Acquisition Data to Dictionary of Natural Products and Dictionary of Marine Natural Products (Table 7). Based on the comparison, peak 13 was tentatively assigned as an unbranched alkenic ketone, peaks $\mathbf{2}$ and 5 as alkaloids, peaks 3, 6 and $\mathbf{1 1}$ as steroids, peak $\mathbf{4}$ as a meroterpenoid, peaks 9,10 and 17 as diterpenoids, peaks 14 and 16 as sesquiterpenoids, and peak 8 as a triterpenoid. The remaining four peaks did not match any data in the above mentioned dictionaries (peak 1, 7, 12 and 15). Peak $\mathbf{i}$ (at $16.4 \mathrm{~min}$ ) in A7 fraction and peak 12 (at $16.3 \mathrm{~min}$ ) in the chloroform extract shared the same accurate mass at 768.4909; while peak ii (at $21.6 \mathrm{~min}$ ) in A7 fraction corresponded to peak 13 (at $21.7 \mathrm{~min}$ ) [assigned as bis-(3-oxoundecyl) tetrasulfide] in the chloroform extract, yielding an accurate mass of 466.3487. Peaks that shared similar retention times and accurate masses were suggested to be the same compound.

Table 7. LC-MS analysis and database search of main peaks in chloroform extract of Bryopsis pennata (Bryopsidales: Bryopsidaceae).

\begin{tabular}{|c|c|c|c|c|c|}
\hline No & $\begin{array}{c}\text { Rt } \\
(\mathbf{m i n})\end{array}$ & $\begin{array}{c}\text { Accurate } \\
\text { Mass }\end{array}$ & $\begin{array}{l}\text { Possible } \\
\text { Molecular } \\
\text { Formula } \\
\end{array}$ & Possible Hits from Database & $\begin{array}{c}\text { Type of Compound and } \\
\text { Biological Source } \\
\text { (Order: Family) } \\
\end{array}$ \\
\hline 1 & 8.4 & 326.1923 & $\mathrm{C}_{19} \mathrm{H}_{34} \mathrm{O}_{4}$ & No hits & \\
\hline 2 & 8.8 & 370.2187 & $\mathrm{C}_{22} \mathrm{H}_{14} \mathrm{~N}_{2} \mathrm{O}_{4}$ & Caulerpinic acid & $\begin{array}{c}\text { Alkaloid of green seaweed } \\
\text { Caulerpa racemosa } \\
\text { (Bryopsidales: Caulerpaceae) }\end{array}$ \\
\hline 3 & 9.1 & 414.2442 & $\mathrm{C}_{29} \mathrm{H}_{50} \mathrm{O}$ & Sitosterol & $\begin{array}{c}\text { Steroid of green seaweed } \\
\text { Bryopsis plumose } \\
\text { (Bryopsidales: Bryopsidaceae) }\end{array}$ \\
\hline 4 & 9.4 & 340.2079 & $\mathrm{C}_{16} \mathrm{H}_{21} \mathrm{BrO}_{3}$ & Hydroxycymopochromenol & $\begin{array}{l}\text { Meroterpenoid of green seaweed } \\
\text { Cymopolia barbata } \\
\text { (Dasycladales: Dasycladaceae) }\end{array}$ \\
\hline 5 & 9.7 & 384.2342 & $\mathrm{C}_{23} \mathrm{H}_{16} \mathrm{~N}_{2} \mathrm{O}_{4}$ & Monomethyl caulerpinate & $\begin{array}{c}\text { Alkaloid of green seaweed } \\
\text { Caulerpa racemosa } \\
\text { (Bryopsidales: Caulerpaceae) }\end{array}$ \\
\hline 6 & 10.0 & 428.2604 & $\mathrm{C}_{29} \mathrm{H}_{48} \mathrm{O}_{2}$ & Decortinol & $\begin{array}{l}\text { Steroid of green seaweeds } \\
\text { Codium decorticatum and } \\
\text { Codium arabicum } \\
\text { (Bryopsidales: Codiaceae) }\end{array}$ \\
\hline 7 & 10.2 & 472.2874 & $\mathrm{C}_{29} \mathrm{H}_{44} \mathrm{O}_{5}$ & No hits & \\
\hline 8 & 10.4 & 516.3135 & $\mathrm{C}_{34} \mathrm{H}_{60} \mathrm{O}_{3}$ & Botryolin A and B & $\begin{array}{c}\text { Triterpenoid of microalga } \\
\text { Botryococcus braunii } \\
\text { (Trebouxiales: Botryococcaceae) }\end{array}$ \\
\hline 9 & 10.8 & 302.183 & $\mathrm{C}_{20} \mathrm{H}_{30} \mathrm{O}_{2}$ & 2,6,10,14-Phytatetraene-1,20-dial & $\begin{array}{c}\text { Diterpenoid of green seaweed } \\
\text { Caulerpa brownie } \\
\text { (Bryopsidales: Caulerpaceae) }\end{array}$ \\
\hline 10 & 11.1 & 346.2087 & $\mathrm{C}_{22} \mathrm{H}_{34} \mathrm{O}_{3}$ & $\begin{array}{l}\text { 2,6,10,14-Phytatetraene-1,20-diol, } \\
\text { Variant: (2E,6E,10E)-form, } \\
\text { Derivative: 1-Aldehyde, 20-Ac }\end{array}$ & $\begin{array}{l}\text { Diterpenoid of green seaweed } \\
\text { Caulerpa brownie } \\
\text { (Bryopsidales: Caulerpaceae) }\end{array}$ \\
\hline
\end{tabular}


Table 7. Cont.

\begin{tabular}{|c|c|c|c|c|c|}
\hline No & $\begin{array}{c}\text { Rt } \\
(\min )\end{array}$ & $\begin{array}{c}\text { Accurate } \\
\text { Mass }\end{array}$ & $\begin{array}{l}\text { Possible } \\
\text { Molecular } \\
\text { Formula }\end{array}$ & Possible Hits from Database & $\begin{array}{l}\text { Type of Compound and } \\
\text { Biological Source } \\
\text { (Order: Family) } \\
\end{array}$ \\
\hline 11 & 15.8 & 444.2243 & $\mathrm{C}_{29} \mathrm{H}_{48} \mathrm{O}_{3}$ & $\begin{array}{l}\text { 7-Hydroperoxystigmasta-5,25-dien- } \\
\text { 3-ol }\end{array}$ & $\begin{array}{l}\text { Steroid of green seaweed } \\
\text { Codium arabicum } \\
\text { (Bryopsidales: Codiaceae) }\end{array}$ \\
\hline 12 & 16.3 & 768.4909 & $\mathrm{C}_{43} \mathrm{H}_{60} \mathrm{O}_{12}$ & No hits & \\
\hline 13 & 21.7 & 466.3487 & $\mathrm{C}_{22} \mathrm{H}_{42} \mathrm{O}_{2} \mathrm{~S}_{4}$ & Bis-(3-oxoundecyl) tetrasulfide * & $\begin{array}{l}\text { Unbranched alkenic ketone of } \\
\text { brown seaweed Dictyopteris } \\
\text { spp. (Dictyotales: Dictyotaceae) }\end{array}$ \\
\hline 14 & 23.0 & 278.1494 & $\mathrm{C}_{17} \mathrm{H}_{26} \mathrm{O}_{3}$ & $\begin{array}{c}\text { 4-Hydroxy-2-[2-(2,6,6-trimethyl-2- } \\
\text { cyclohexen-1-yl)ethyl]-2-buten-1-al, } \\
\text { Derivative: Ac }\end{array}$ & $\begin{array}{c}\text { Sesquiterpenoid of green } \\
\text { seaweed Caulerpa flexilis } \\
\text { (Bryopsidales: Caulerpaceae) }\end{array}$ \\
\hline 15 & 24.4 & 921.0025 & $\mathrm{C}_{54} \mathrm{H}_{83} \mathrm{NO}_{11}$ & No hits & \\
\hline 16 & 34.9 & 390.2742 & $\mathrm{C}_{21} \mathrm{H}_{26} \mathrm{O}_{7}$ & 10,11-Epoxycaulerpenyne & $\begin{array}{c}\text { Sesquiterpenoid of green } \\
\text { seaweed Caulerpa taxifolia } \\
\text { (Bryopsidales: Caulerpaceae) }\end{array}$ \\
\hline 17 & 35.4 & 390.2749 & $\mathrm{C}_{24} \mathrm{H}_{38} \mathrm{O}_{4}$ & Trifarin & $\begin{array}{l}\text { Diterpenoid of green seaweed } \\
\text { Caulerpa flexilis } \\
\text { (Bryopsidales: Caulerpaceae) }\end{array}$ \\
\hline
\end{tabular}

* Suggested compound for peak $\mathbf{1 3}$ of chloroform extract LC-MS profile and peak ii of fraction A7 LC-MS profile.

\subsection{Discussion}

Development of new insecticides based on natural products requires a thorough understanding of the potential activity of natural products against mosquito at each stage of the insect's life. Furthermore, the information on toxic effect of bioinsecticides against non-target organisms serves a useful basis for the development of safer and more selective mosquitocidal agents. In this study, dengue vectors of Ae. aegypti and Ae. albopictus were used as a model system and brine shrimp nauplii was used as non-target organism, to investigate the potential of different extracts of seaweed B. pennata.

Applications of ovicide and larvicide are effective strategies to control the population of mosquito since controlling the egg and larva that live in bounded aquatic area is easier compared to targeting the free-flying adult [19]. Furthermore, as dengue virus is transmitted transovarially by mosquito, ovicide could be the solution to suppress the vector population. Therefore, inhibiting the egg hatchability, larval emergence, and oviposition of gravid female are the main aims of ovicidal agent in mosquito control. Previous studies showed that treatment of plant extract induces morphometric changes to the mosquito egg that inhibits the development of the egg, such as swelling with increase in length of the egg and deformities in air floats [20]. Furthermore, studies also revealed that plants had promising ovicidal and oviposition repellent effects against Ae. aegypti [21-23]. However, ovicidal and oviposition repellent potentials of seaweeds have not been studied much. Interestingly, the ovicidal and oviposition repellent properties of chloroform and methanol extracts of B. pennata in our report are comparable to that of other reports [21,24]. 
Earlier studies have suggested that seaweeds also exhibit skin repellent and smoke repellent properties against adult mosquitoes [25,26], but little information about the adulticidal properties of seaweed. In our report, chloroform extract of $B$. pennata resulted in the strongest adulticidal effect among the extracts tested, but it was considered as an ineffective adulticidal agent against Ae. aegypti when compared to extract of monocot flowering plant Acorus calamus (LC50 value of $0.04 \mathrm{mg} / \mathrm{cm}^{2}$ ) and essential oil of wild sage Lantana camara (LC50 value of $0.06 \mathrm{mg} / \mathrm{cm}^{2}$ ) [27,28]. On the other hand, the mosquitocidal activities of bioinsecticides are comprised of both toxic and behavioural effects [29]. In the present study, the observation of abnormal behaviour changes of adult females after treatment of seaweed extract is in agreement with previous studies using other plant extracts $[28,30]$ and these symptoms were also similar to those caused by nerve poison [31].

The use of seaweeds as effective mosquito larvicide has been reported by researchers [18,32]. Furthermore, Bianco et al. [17] reported that hexane extract of red seaweed Laurencia dendroidea had strong larvicidal effect by causing $100 \%$ mortality at $50 \mathrm{ppm}$ against Ae. aegypti larvae. Sequential fractionation of the hexane extract of $L$. dendroidea yielded elatol that exhibited $\mathrm{LC}_{50}$ value of $10.7 \mathrm{ppm}$ against Ae. aegypti larvae. This demonstrates that pure compound has higher efficiency in larvicidal activity when separated from the extract (with a combination of compounds), due to a higher concentration of the compound being available for bioactivity action. Our findings are in line with the finding of Bianco et al. [17] showing A7 fraction of B. pennata exhibited more than 15-fold stronger larvicidal effect as compared to the extracts. In addition, the larvicidal activity of A7 fraction in the present study is comparable to other larvicidal compounds derived from either terrestrial plants or seaweeds [18,33,34].

Apart from that, $\beta$-sitosterol (the anomer of compound which assigned as peak 3 in the LC-MS analysis of chloroform extract), was reported as an active mosquito larvicidal compound isolated from the petroleum ether extract of shrub Abutilon indicum in a previous report with the $\mathrm{LC}_{50}$ value of 11.49 ppm against Ae. aegypti [35]. However, the presence of sitosterol in the present study did not have a significant effect on the larvicidal action as compared to the previous study. The bioactivity of plant extracts and fractions depends on the biomass production and chemical composition which highly related to the natural variability and sample preparation $[18,36]$. Therefore, it is suggested that sitosterol may have a lower concentration in the extracts of $B$. pennata due to different species and extraction methods; hence the weak larvicidal effect on mosquitos in the present study.

In view of the active larvicidal activity of the A7 fraction, the compounds present in the A7 fraction were assumed to correlate with the strong mosquito larvicidal effect. The match of peak $\mathbf{1 3}$ [assigned as bis-(3-oxoundecyl) tetrasulfide] or ii of LC-MS analysis in the dictionary suggested that the compound has an unbranched long hydrocarbon chain with carbonyl group (Figure 3). This is in line with the previous reports that described active mosquito larvicidal compounds with their chemical characteristics such as lipophilic profile [37] and possession of double bond [38]. For example, aliphatic fatty acids with a long hydrocarbon chain derived from green seaweed Cladophora glomerata (having LC 50 values of 3-14 ppm against Aedes triseriatus) [39] and alkaloids with double bond isolated from green seaweed Caulerpa racemosa (having LC50 values of 1.4-4.8 ppm against Culex pipiens) [40]. Further confirmation of the identity of peak $\mathbf{1 3}$ or ii and its larvicidal activity is warranted, as the literature on bis-(3-oxoundecyl) tetrasulfide is limited [41,42]. 


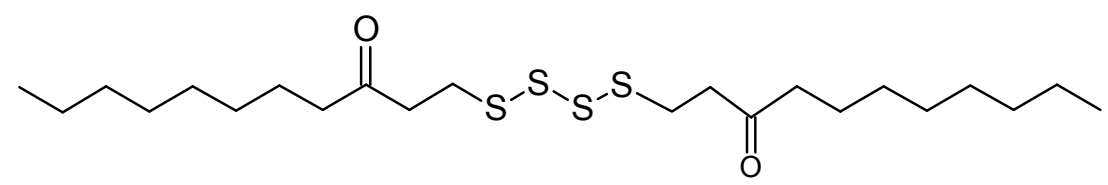

Figure 3. Bis-(3-oxoundecyl) tetrasulfide (possible hit of Peak 13 or ii from Dictionary of Marine Natural Products).

In spite of exhibiting killing action towards mosquito at different stages of its life cycle, seaweed has been proven to have deleterious impact on the morphological structure and behaviour of the treated mosquitoes [17,32]. These symptoms were noted in our observation of the study. Structural alteration of anal papillae of mosquito larvae leads to its dysfunctionality which may result an interruption of osmosis and ionic regulations $[43,44]$. Osmosis and ionic imbalance of the mosquito larvae may be intrinsically associated with the larval death or may be part of the mechanism causing the death of mosquito larvae [45]. Furthermore, the rupture of larva's inner structure of spiracular apparatus observed in the present report is suggested to cause destruction to the hydrophobic surface of stigmal plate, causing water/medium to enter the tracheal trunk which harms the respiration system of the larvae [46,47]. On the other hand, the abnormal behaviour of intoxicated larvae might be due to the effect of insecticidal extracts that affects the neuromuscular coordination in chemical synapses [48]. In addition, interaction with the picrotoxinin receptor of insect central nervous system (cyclodiene-type mechanism) is proposed to be one of the action modes of insecticidal compounds derived from seaweeds [49].

An effective mosquitocidal agent should be target-specific but pose little risk to the non-target organism. Therefore, the brine shrimp nauplii toxicity test offers a relatively rapid and convenient method to assess the toxic effect of natural products [50]. Various seaweeds have been tested for their toxicity against brine shrimp nauplii [18]. In our report, B. pennata induced strong larvicidal effect towards Aedes mosquito but weak toxic effect towards brine shrimp nauplii. A similar trend was observed in the study of brown seaweed Padina gymnospora reported by Guedes et al. [51].

To the best of our knowledge, this is the first report on the mosquitocidal properties of green seaweed B. pennata against dengue vectors Ae. aegypti and Ae. albopictus. Although the present study demonstrated the mosquitocidal potential of $B$. pennata, identification of active compounds and their mechanism of action, as well as their possible synergistic effect, may allow the development of bioinsecticides with greater potency than the extract and fraction evaluated here. Chemical synthesis of the active larvicidal analogues and formulation of binary insecticides may also provide useful end products. In addition, the insecticide should be tested on different mosquito species and in the field to ensure its efficacy.

\section{Experimental Section}

\subsection{Preparation of Seaweed Extracts}

Fresh B. pennata (voucher number: CRM-C1) was collected in October to December of 2012 from Teluk Kemang $\left(2^{\circ} 26.29^{\prime} \mathrm{N}, 101^{\circ} 51.42^{\prime} \mathrm{E}\right)$, Port Dickson, Malaysia. The sample was identified and voucher specimen was deposited at the herbarium maintained by Faculty of Science and Technology, Universiti Kebangsaan Malaysia. Dried sample was ground, sieved, macerated for $72 \mathrm{~h}$ with methanol (Merck, Darmstadt, Germany) (60 g/L), and stirred with the aid of magnetic stirrer. The sample was 
extracted 3 times. Then, the solvent was filtered and concentrated by using Rotavapor ${ }^{\circledR} \mathrm{R}-210$ rotary evaporator (Buchi, Flawil, Switzerland) at $50{ }^{\circ} \mathrm{C}$ to dryness to yield the methanol extract [52]. The methanol extract was liquid-liquid partitioned to hexane, aqueous and chloroform extracts [53] (Figure 4). These extracts were again concentrated by using rotary evaporator and kept in vials at $4{ }^{\circ} \mathrm{C}$ prior to mosquito assay. The most active extract of $B$. pennata in mosquito larvicidal assay was fractioned by using vacuum liquid chromatography (VLC) (Rocker Scientific Co., Ltd., Taipei, Taiwan). Then, the fractions were combined based on the pattern of thin layer chromatography (TLC) (Merck).

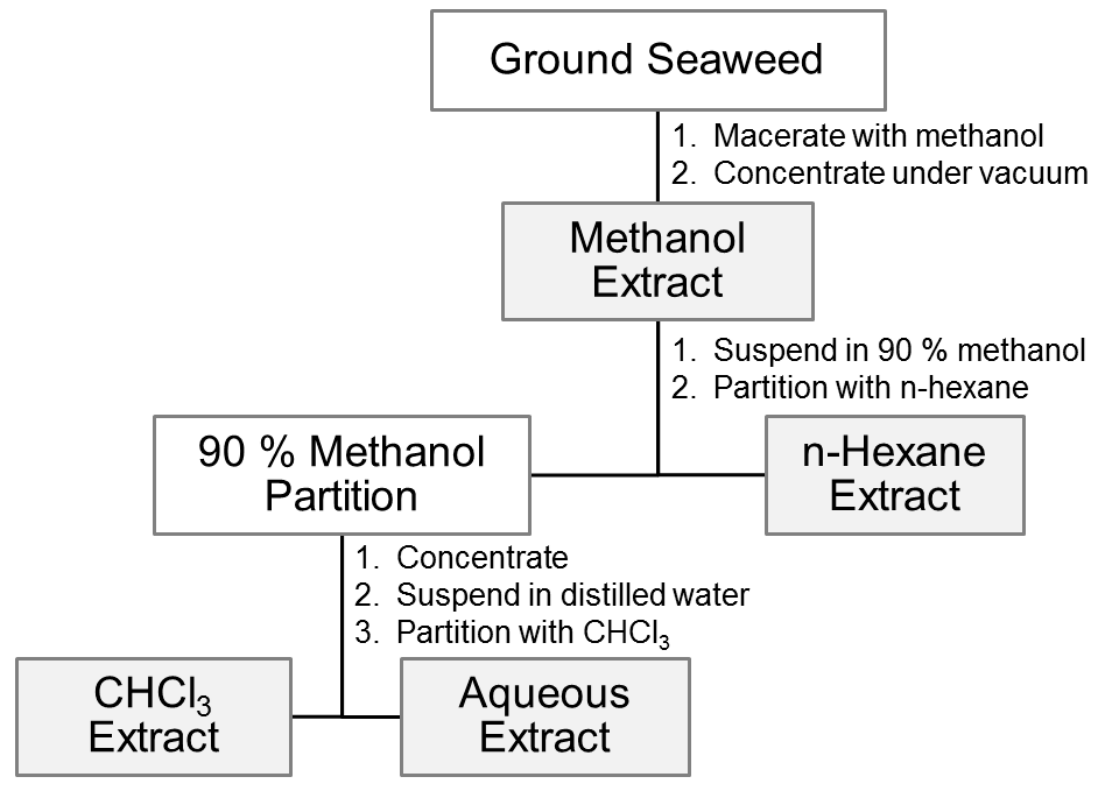

Figure 4. Procedure for preparing extracts representing a range of polarities. Source: Adapted from Jones and Kinghorn [53].

\subsection{Maintaining Mosquito Culture}

Laboratory strains of Ae. aegypti and Ae. albopictus were obtained from the insectary of the Institute for Medical Research (IMR), Malaysia. The colony was maintained at the temperature of $26 \pm 1{ }^{\circ} \mathrm{C}$ and relative humidity of $80 \% \pm 5 \%$. The mosquito larvae were reared in a plastic tray filled with de-chlorinated water and fed with liver powder and half cooked beef liver. Pupae were collected and transferred into an enamel bowl filled with water which was later placed in a mosquito cage $(30 \times 30 \times 30 \mathrm{~cm})$ for adult emergence. Adults were provided with 10\% sucrose solution mixed with Vitamin B, and restrained mice for blood meal. Bowls containing de-chlorinated water and fitted with filter paper were placed in the mosquito cage as ovitrap to collect egg. The procedures for colonization, feeding and use of mosquitoes of Entomology Unit, Infectious Disease Research Centre, IMR have been followed. These procedures were in accordance with the Section 14, Destruction of Disease-Bearing Insects Act 1975 (amended 2000) and approved by the Ministry of Health, Malaysia in 2006. 


\subsection{Mosquito Ovicidal Assay}

Freshly laid intact mosquito eggs (30 to 50 eggs per batch) of Ae. aegypti and Ae. albopictus were exposed to seaweed extract solutions of different concentrations (100 to $500 \mu \mathrm{g} / \mathrm{mL}$ ) in $50-\mathrm{mL}$ container for $5 \mathrm{~h}$. After that, the eggs were transferred into paper cups filled with distilled water and allowed for hatching [21]. The seaweed extract solutions were prepared in $0.1 \%(v / v)$ of methanol solution. Larvae that emerged from the treated eggs were counted under Leica EZ4HD stereomicroscope (Leica Microsystems Inc., Buffalo Grove, IL, USA) every $24 \mathrm{~h}$ for 7 days before being removed from the container. Eggs with unopened opercula were considered as unhatched/dead eggs. Ovicidal activity was calculated as percentage of unhatched/dead egg after 7 days. Negative control of the experiment was prepared by soaking the eggs from the same batch in $0.1 \%(v / v)$ of methanol solution, while positive control was prepared by soaking the eggs into Abate ${ }^{\circledR} 1.1 \mathrm{G}$ (Temephos $1.1 \%$ w/w) $(0.011 \mathrm{~g} / \mathrm{mL}$ ) (BASF (Malaysia) Sdn. Bhd., Shah Alam, Selangor, Malaysia). The experiment was carried out 3 times with triplicates. The LC 50 value and chi-square were calculated by using the probit analysis of IBM SPSS Statistics version 20 software (IBM Corp., Armonk, NY, USA).

\subsection{Mosquito Larvicidal Assay}

The larvicidal assay was conducted according to the guidelines of the World Health Organization [54] with slight modifications. The larvicidal assay was performed by using extracts and followed by the fractions (yielded from the active extracts). The fourth instar larvae were divided into a few batches with each batch constituting 25 larvae. They were then put into different $200 \mathrm{~mL}$-paper cups filled with extract/fraction of various concentrations, which had been prepared through dilution of stock solution in distilled water. Abate ${ }^{\circledR} 1.1 \mathrm{G}$ (Temephos $1.1 \%$ w/w) $(0.011 \mathrm{~g} / \mathrm{mL})$ (BASF (Malaysia) Sdn. Bhd.) was used as positive control and $0.1 \%(v / v)$ of methanol was used as negative control. The behaviour of the treated larvae was observed hourly for $24 \mathrm{~h}$. The larvae were considered dead if they did not move when the water was disturbed. The larval mortality was recorded at the end of 24-h monitoring. The experiment was repeated 5 times with triplicates. The $\mathrm{LC}_{50}$ value and chi-square were calculated by using the probit analysis of IBM SPSS Statistics version 20 software (IBM Corp.).

The morphology of treated larvae was examined and recorded by using stereo microscope and scanning electron microscope (SEM) after the 24-h treatment. For stereo microscope study, the larvae were fixed in $80 \%$ ethanol and observed under stereomicroscope Leica EZ4HD (Leica Microsystems Inc., Buffalo Grove, IL, USA) [55]. SEM study was done according to Neves Filho et al. [47] with modifications. The larvae were rinsed with distilled water, followed by $8 \%$ of glutaraldehyde and Sorensen's phosphate buffer (for $1 \mathrm{~h}$ ), Sorensen's phosphate buffer and distilled water (1:1) (for $1 \mathrm{~h}$ ), and 4\% of osmium tetroxide (Sigma-Aldrich, St. Louis, MO, USA) and distilled water $(1: 3)$ at the temperature of $4{ }^{\circ} \mathrm{C}$ (for $14 \mathrm{~h}$ ). After that, the larvae were subjected to dehydration in serial alcohol and acetone, followed by drying by using critical point dryer CPD300 (Leica Microsystems Inc.), and subsequently the larvae were mounted. Then, the larvae were spurted with $45 \mathrm{~nm}$ gold for $1 \mathrm{~min}$ by using auto fine coater JFC-1600 (JEOL Ltd., Tokyo, Japan). Finally, the larvae were viewed and recorded by using thermal field emission scanning electron microscope JSM-7001F (JEOL Ltd.). 


\subsection{Mosquito Adulticidal Assay}

Adulticidal assay was carried out according to the guidelines of World Health Organization [56] with slight modifications. Stock solutions $(10,000 \mu \mathrm{g} / \mathrm{mL})$ were prepared by dissolving seaweed extract in methanol solution. Impregnated papers were prepared freshly prior to testing. Each filter paper $(140 \times 115 \mathrm{~mm})$ was impregnated with $4 \mathrm{~mL}$ of solution making final concentrations of $0.248,0.496$, 0.993 and $1.987 \mathrm{mg} / \mathrm{cm}^{2}$. Then, the impregnated papers were left to air-dry at temperature of $25 \pm 2{ }^{\circ} \mathrm{C}$. Malathion impregnated filter paper (WHO, Geneva, Switzerland) was used as a positive control at a diagnostic dosage of $5 \%(v / v)$. The filter papers used for negative control were impregnated with $5 \%$ $(v / v)$ methanol solution. Different batches formed by 15 adult females each were introduced to the exposure tubes (WHO, Geneva, Switzerland) with an impregnated paper in each tube for $3 \mathrm{~h}$. At the end of the 3-h exposure, the mosquitoes were transferred to a holding tube (WHO) and given 10\% sugar solution enriched with Vitamin B complex as food. The behaviour of the treated adults was observed hourly. The mosquito was considered dead if it showed no response, no sign of movement and lying on the holding tube. Mortality was recorded after $24 \mathrm{~h}$. The experiment was repeated 3 times with triplicates. The LC 50 value and chi-square were calculated by using the probit analysis of IBM SPSS Statistics version 20 software (IBM Corp.).

\subsection{Mosquito Oviposition Assay}

Gravid female adults which have given blood meal 3 days ago were released into mosquito cages $(30 \times 30 \times 30 \mathrm{~cm})(15$ females per cage $)$. Solutions of seaweed extract were prepared in different concentrations (50-400 $\mu \mathrm{g} / \mathrm{mL}$ ). Plastic bowl containing filter paper folded in cone shape (as oviposition site) and $50 \mathrm{~mL}$ of test solution was used as ovitrap. One control ovitrap (containing $0.20 \% v / v$ of methanol) and one test ovitrap (containing seaweed extract) were placed diagonally at the opposite corners of each mosquito cage. The positions of ovitraps were rotated between the different replicates to counteract the position effect. Filter paper in the ovitrap was replaced every $24 \mathrm{~h}$ for 3 days and the number of eggs laid on the filter paper were counted under stereomicroscope Leica EZ4HD (Leica Microsystems Inc.). The experiment was carried out 3 times with triplicates [21]. All experiments were conducted at temperature of $26 \pm 2{ }^{\circ} \mathrm{C}$ and relative humidity of $80 \% \pm 2 \%$. One-way analysis of variance (ANOVA) followed by Tukey test of IBM SPSS Statistics version 20 software (IBM Corp.) were used to determine significant differences between the treatments.

Effective repellency (ER\%) [57] and oviposition active index (OAI) [58] were calculated by using the following formulas:

$$
\begin{gathered}
\mathrm{ER} \%=\frac{(\mathrm{NT}-\mathrm{NC})}{\mathrm{NC}} \times 100 \\
\mathrm{OAI}=\frac{(\mathrm{NT}-\mathrm{NC})}{(\mathrm{NT}+\mathrm{NC})}
\end{gathered}
$$

NT is the total number of eggs laid in the extract solution, and NC is the total number of eggs laid in the control solution.

The treatment with OAI value of +0.3 or above is considered as oviposition attractant while the treatment with OAI value of -0.3 or below is considered as oviposition repellent [58]. Positive value 
indicates that the test solution was an attractrant for oviposition, as more eggs were deposited in the test ovitrap than in the control ovitrap. On the other hand, negative value indicates that the test solution was a deterrent for oviposition, as more eggs were deposited in the control ovitrap than in the test ovitrap [21].

The $\mathrm{RC}_{50}$ value (concentration that caused 50\% repellency) and chi-square were calculated by using the probit analysis of IBM SPSS Statistics version 20 software (IBM Corp.). One-way analysis of variance (ANOVA) followed by Tukey test using IBM SPSS Statistics version 20 software was used to determine significant differences between the treatments.

\subsection{Brine Shrimp Toxicity Assay}

Each batch of 10 newly hatched Artemia salina nauplii was introduced to $5 \mathrm{~mL}$ of seaweed extract solution with concentrations ranging from 300 to $600 \mu \mathrm{g} / \mathrm{mL}$. The seaweed extract solution was prepared by using stock solution $(20 \mathrm{mg} / \mathrm{mL})$ and brine medium $(15 \mathrm{mg}$ of sea salt in $1 \mathrm{~mL}$ of distilled water). Three replicates were prepared for each test sample and the experiment was repeated 3 times [50]. Potassium dichromate solution $(25 \mu \mathrm{g} / \mathrm{mL})$ (Sigma-Aldrich.) was used as a positive control and $0.1 \%$ $(v / v)$ methanol in brine medium was prepared as negative control. The mortality of nauplii was recorded after $24 \mathrm{~h}$. The $\mathrm{LC}_{50}$ value and chi-square were calculated by using the probit analysis of IBM SPSS Statistics version 20 software (IBM Corp.).

\subsection{Liquid Chromatography-Mass Spectrometry Analysis}

The sample was prepared in methanol with the concentration of $20 \mu \mathrm{g} / \mathrm{mL}$ and filtered through a $0.45 \mu \mathrm{m}$ nylon membrane (Merck Millipore (UK) Ltd., Feltham, UK) before being loaded into the system. The sample was analyzed by using Agilent 6530 Accurate-Mass Q-TOF liquid chromatography-mass spectrometry (LC-MS) system with Agilent Zorbax Eclipse XDB-C18 column $(2.1 \times 50 \mathrm{~mm}, 1.8$ micron) (Agilent Technologies Inc., Mississauga, ON, Canada), and eluted with acetonitrile (Merck) and water using gradient system. The mobile phase started with $99.5 \%$ of water and decreased to $50 \%$ of water over $10 \mathrm{~min}$, followed by $50 \%$ of water and decreased to $0 \%$ over $25 \mathrm{~min}$ and then held at $0 \%$ of water for $5 \mathrm{~min}$, and finally increased to $99.5 \%$ of water over $3 \mathrm{~min}$, at a flow rate of $0.25 \mathrm{~mL} / \mathrm{min}$. The experiments were performed in the positive ion mode. The flow rate of the drying gas was set at $8 \mathrm{~L} / \mathrm{min}$ at the temperature of $350^{\circ} \mathrm{C}$. The nebulizer pressure was set at 35 PSIG with the capillary and injection volume set at $3000 \mathrm{~V}$ and $5 \mu \mathrm{L}$, respectively.

Data of retention time and accurate mass of molecular ions were processed by using qualitative analysis software of Mass Hunter Acquisition Data (Agilent Technologies Inc.) to provide a list of possible molecular formula. Then, accurate mass data and molecular formula were used to corroborate with the data in Dictionary of Natural Products [59] and Dictionary of Marine Natural Products [60]. During the comparison of data, factors like biological resource, compound category and polarity's reasonability were taken into account to rule out the unreasonable hits [61].

\subsection{Data Analysis}

Mortality of the eggs or larvae or adults in negative control which was $5 \%$ to $20 \%$ was corrected by Abbott's formula [62]. The effect of different treatments were compared through one way analysis of 
variance (ANOVA) followed by Tukey test, using IBM SPSS Statistics version 20 (IBM Corp.). $p<0.05$ was considered to be statistically significant.

\section{Conclusions}

The understanding of mosquitocidal potential of $B$. pennata helps in discovering the potential of this natural derived insecticide in the vector control research. This study demonstrated that chloroform extract of B. pennata had strong larvicidal, ovicidal as well as oviposition repellence properties against Ae. aegypti and Ae. albopictus with mild toxic effect against non-target organism (nauplii of A. salina). The results from the LC-MS profiling suggested that the contributing compound for the larvicidal effect is an aliphatic compound. Further confirmation of the responsible compound by using other techniques is highly recommended. Since $B$. pennata is a common seaweed found along the coasts of tropical regions, its availability makes further investigation, development and commercialization possible.

\section{Acknowledgments}

The authors are thankful to Faculty of Pharmacy of Universiti Kebangsaan Malaysia, Medical Entomology Unit of Infectious Disease Research Centre of Institute for Medical Research, School of Biosciences of Taylor's University, and Faculty of Engineering and Science of Universiti Tunku Abdul Rahman for financial assistance and technical support. The help of Miss Chiong Kai Shing for proof reading is greatly acknowledged.

\section{Author Contributions}

I.J., R.A. and C.-L.W. conceived and designed the study. K.-X.Y performed the experiment and wrote the paper. K.-X.Y, I.J., R.A. and C.-L.W. analyzed the data. I.J., R.A. and C.-L.W. contributed reagents, materials and analysis tools. All authors read and approved the final manuscript.

\section{Conflicts of Interest}

The authors declare no conflict of interest.

\section{References and Notes}

1. World Health Organization. Impact of Dengue. Available online: http://www.who.int/csr/disease/ dengue/impact/en/ (accessed on 29 May 2015).

2. Ooi, E.E.; Gubler, D.J. Global spread of epidemic dengue: The influence of environmental change. Future Virol. 2009, 4, 571-580.

3. Shepard, D.S.; Coudeville, L.; Halasa, Y.A.; Zambrano, B.; Dayan, G.H. Economic impact of dengue illness in the Americas. Am. J. Trop. Med. Hyg. 2011, 84, 200-207.

4. Lee, H.L. Aedes: Mosquito that spread dengue fever. In Mosquitoes and Mosquito-Borne Diseases: Biology, Surveillance, Control, Personal and Public Protection Measures; Ng, F.S.P., Yong, H.S., Eds.; Academy of Sciences Malaysia: Kuala Lumpur, Malaysia, 2000; pp. 45-63.

5. World Health Organization. Guidelines for Dengue Surveillance and Mosquito Control. Available online: http://www.wpro.who.int/publications/pub_9290610689/en/(accessed on 5 January 2015). 
6. Lee, H.L. Environmental friendly approaches to mosquito control. In Mosquitoes and Mosquito-Borne Diseases: Biology, Surveillance, Control, Personal and Public Protection Measures; Ng, F.S.P., Yong, H.S., Eds.; Academy of Sciences Malaysia: Kuala Lumpur, Malaysia, 2000; pp. 223-234.

7. Coppejans, E.; Leliaert, F.; Dargent, O.; Gunasekara, R.; de Clerck, O. Sri Lankan Seaweeds: Methodologies and field guide to the dominant species. In Abc Taxa; Samyn, Y., Vandenspiegel, D., Degreef, J., Eds.; The Belgian Development Cooperation: Brussels, Belgium, 2009; Volume 6, pp. 100-101.

8. Usmanghani, K.; Shameel, M.; Sualeh, M.; Khan, K.; Mahmood, Z. Antibacterial and antifungal activities of marine algae from Karachi seashore of Pakistan. Fitoterapia 1984, 55, 73-77.

9. Puglisi, M.P.; Engel, S.; Jensen, P.R.; Fenical, W. Antimicrobial activities of extracts from Indo-Pacific marine plants against marine pathogens and saprophytes. Mar. Biol. 2007, 150, 531-540.

10. Freitas, J.C.; Sakamoto, M.I.; Caprara, L. Cardiac effects induced by extract of the seaweed Bryopsis pennata (Chlorophyta, Caulerpales). Toxicon 1995, 33, doi:10.1016/0041-0101(95)99356-8.

11. Hamann, M.T.; Scheuer, P.J.; Kahalalide, F. A bioactive depsipeptide from the sacoglossan mollusk Elysia rufescens and the green alga Bryopsis sp. J. Am. Chem. Soc. 1993, 115, 5825-5826.

12. Rademaker-Lakhai, J.M.; Horenblas, S.; Meinhardt, W.; Stokvis, E.; de Reijke, T.M.; Jimeno, J.M.; Lopez-Lazaro, L.; Lopez Martin, J.A.; Beijnen, J.H.; Schellens, J.H.M. Phase I clinical and pharmacokinetic study of Kahalalide $\mathrm{F}$ in patients with advanced androgen refractory prostate cancer. Clin. Cancer Res. 2005, 11, 1854-1862.

13. Biju, B.; Jacob, M.; Padmakumar, K.; Muraleedharan, D. Effect of extract of the seaweed Bryopsis plumosa (Huds.) Ag. on the feeding rate and protein profile of haemolymph and fat body of Hyblaea puera (Cramer) (Lepidoptera: Hyblaeidae). Entomon 2014, 29, 271-276.

14. Smit, A.J. Medicinal and pharmaceutical uses of seaweed natural products: A review. J. Appl. Phycol. 2004, 16, 245-262.

15. Ali, M.Y.S.; Ravikumar, S.; Beula, J.M. Mosquito larvicidal activity of seaweeds extracts against Anopheles stephensi, Aedes aegypti and Culex quinquefasciatus. Asian Pac. J. Trop. Dis. 2013, 3, 196-201.

16. Beula, J.M.; Ravikumar, S.; Ali, M.S. Mosquito larvicidal efficacy of seaweed extracts against dengue vector of Aedes aegypti. Asian Pac. J. Trop. Biomed. 2011, 1, S143-S146.

17. Bianco, E.M.; Pires, L.; Santos, G.K.; Dutra, K.A.; Reis, T.N.; Vasconcelos, E.R.; Cocentino, A.L.; Navarro, D.M. Larvicidal activity of seaweeds from northeastern Brazil and of a halogenated sesquiterpene against the dengue mosquito Aedes aegypti. Ind. Crop. Prod. 2013, 43, 270-275.

18. Yu, K.X.; Jantan, I.; Ahmad, R.; Wong, C.L. The major bioactive components of seaweeds and their mosquitocidal potential. Parasitol. Res. 2014, 113, 3121-3141.

19. Carvalho, A.F.U.; Melo, V.M.M.; Craveiro, A.A.; Machado, M.I.L.; Bantim, M.B.; Rabelo, E.F. Larvicidal activity of the essential oil from Lippia sidoides Cham. against Aedes aegypti Linn. Mem. Inst. Oswaldo Cruz 2003, 98, 569-571.

20. Sharma, P.; Mohan, L.; Srivastava, C.N. Impact analysis of neem kernel extracts on the developmental profile of Anopheles stephensi. J. Asia -Pac. Entomol. 2006, 9, 11-17.

21. Cheah, S.X.; Tay, J.W.; Chan, L.K.; Jaal, Z. Larvicidal, oviposition, and ovicidal effects of Artemisia annua (Asterales: Asteraceae) against Aedes aegypti, Anopheles sinensis, and Culex quinquefasciatus (Diptera: Culicidae). Parasitol. Res. 2013, 112, 3275-3282. 
22. Govindarajan, M.; Sivakumar, R. Ovicidal, larvicidal and adulticidal properties of Asparagus racemosus (Willd.) (Family: Asparagaceae) root extracts against filariasis (Culex quinquefasciatus), dengue (Aedes aegypti) and malaria (Anopheles stephensi) vector mosquitoes (Diptera: Culicidae). Parasitol. Res. 2014, 113, 1435-1449.

23. Kovendan, K.; Murugan, K.; Kumar, P.M.; Thiyagarajan, P.; William, S.J. Ovicidal, repellent, adulticidal and field evaluations of plant extract against dengue, malaria and filarial vectors. Parasitol. Res. 2013, 112, 1205-1219.

24. Reegan, A.D.; Kinsalin, A.V.; Paulraj, M.G.; Ignacimuthu, S. Larvicidal, ovicidal, and repellent activities of marine sponge Cliona celata (Grant) extracts against Culex quinquefasciatus Say and Aedes aegypti L. (Diptera: Culicidae). ISRN Entomol. 2013, 2013, doi:10.1155/2013/315389.

25. Kumar, K.P.; Murugan, K.; Kovendan, K.; Kumar, A.N.; Hwang, J.S.; Barnard, D.R. Combined effect of seaweed (Sargassum wightii) and Bacillus thuringiensis var. israelensis on the coastal mosquito, Anopheles sundaicus. Tamil Nadu India Sci. Asia 2012, 38, 141-146.

26. Thangam, T.S.; Kathiresan, K. Marine Plants for Mosquito Control. In Proceedings of the Second International Conference on Urban Pests, Edinburgh, Scotland, UK, 7-10 July 1996; Wildey, K.B., Ed.; pp. 431-435.

27. Hidayatulfathi, O.; Sallehuddin, S.; Ibrahim, J. Adulticidal activity of some Malaysian plant extracts against Aedes aegypti Linnaeus. Trop. Biomed. 2004, 21, 61-67.

28. Dua, V.K.; Pandey, A.C.; Dash, A.P. Adulticidal activity of essential oil of Lantana camara leaves against mosquitoes. Indian J. Med. Res. 2010, 131, 434-439.

29. Isman, M.B. Botanical insecticides, deterrents, and repellents in modern agriculture and an increasingly regulated world. Annu. Rev. Entomol. 2006, 51, 45-66.

30. Govindarajan, M.; Sivakumar, R. Adulticidal and repellent properties of indigenous plant extracts against Culex quinquefasciatus and Aedes aegypti (Diptera: Culicidae). Parasitol. Res. 2012, 110, 1607-1620.

31. Choochote, W.; Tuetun, B.; Kanjanapothi, D.; Rattanachanpichai, E.; Chaithong, U.; Chaiwong, P.; Jitpakdi, A.; Tippawangkosol, P.; Riyong, D.; Pitasawat, B. Potential of crude seed extract of celery, Apium graveolens L., against the mosquito Aedes aegypti (L.) (Diptera: Culicidae). J. Vector Ecol. 2004, 29, 340-346.

32. Manilal, A.; Thajuddin, N.; Selvin, J.; Idhayadhulla, A.; Kumar, R.S.; Sujith, S. In vitro mosquito larvicidal activity of marine algae against the human vectors, Culex quinquefasciatus (Say) and Aedes aegypti (Linnaeus) (Diptera: Culicidae). Int. J. Zool. Res. 2011, 7, 272-278.

33. Dias, C.N.; Moraes, D.F.C. Essential oils and their compounds as Aedes aegypti L. (Diptera: Culicidae) larvicides: Review. Parasitol. Res. 2014, 113, 565-592.

34. Ghosh, A.; Chowdhury, N.; Chandra, G. Plant extracts as potential mosquito larvicides. Indian J. Med. Res. 2012, 135, 581-598.

35. Rahuman, A.A.; Gopalakrishnan, G.; Venkatesan, P.; Geetha, K. Isolation and identification of mosquito larvicidal compound from Abutilon indicum (Linn.) Sweet. Parasitol. Res. 2008, 102, 981-988.

36. Karmegam, N.; Sakthivadivel, M.; Anuradha, V.; Daniel, T. Indigenous-plant extracts as larvicidal agents against Culex quinquefasciatus Say. Bioresour. Technol. 1997, 59, 137-140. 
37. Barbosa, J.D.; Silva, V.B.; Alves, P.B.; Gumina, G.; Santos, R.L.; Sousa, D.P.; Cavalcanti, S.C. Structure-activity relationships of eugenol derivatives against Aedes aegypti (Diptera: Culicidae) larvae. Pest Manag. Sci. 2012, 68, 1478-1483.

38. Laurens, A.; Fourneau, C.; Hocquemiller, R.; Cavé, A.; Bories, C.; Loiseau, P.M. Antivectorial activities of cashew nut shell extracts from Anacardium occidentale L. Phytother. Res. 1997, 11, $145-146$.

39. LaLonde, R.T.; Morris, C.D.; Wong, C.F.; Gardner, L.C.; Eckert, D.J.; King, D.R.; Zimmerman, R.H. Response of Aedes triseriatus larvae to fatty acids of Cladophora. J. Chem. Ecol. 1979, 5, 371-381.

40. Alarif, W.M.; Abou-Elnaga, Z.S.; Ayyad, S.E.N.; Al-lihaibi, S.S. Insecticidal metabolites from the green alga Caulerpa racemosa. Clean Soil Air Water 2010, 38, 548-557.

41. Moore, R.E. Bis-(3-oxoundecyl) polysulphides in Dictyopteris. J. Chem. Soc. D Chem. Commun. 1971, 1168b-1169, doi:10.1039/C2971001168B.

42. Sarma, N.S.; Krishna, M.S.R.; Pasha, S.G. Marine algal natural products: Contributions from India in the global context. Indian J. Chem. Sec. B 2006, 45B, 433-449.

43. Chaithong, U.; Choochote, W.; Kamsuk, K.; Jitpakdi, A.; Tippawangkosol, P.; Chaiyasit, D.; Champakaew, D.; Tuetun, B.; Pitasawat, B. Larvicidal effect of pepper plants on Aedes aegypti (L.) (Diptera: Culicidae). J. Vector Ecol. 2006, 31, 138-144.

44. Insun, D.; Choochote, W.; Jitpakdi, A.; Chaithong, U.; Tippawangkosol, P.; Pitasawat, B. Possible site of action of Kaempferia galanga in killing Culex quinquefasciatus larvae. Southeast Asian J. Trop. Med. Public Health 1999, 30, 195-199.

45. Green, M.M.; Singer, J.M.; Sutherland, D.J.; Hibben, C.R. Larvicidal activity of Tagetes minuta (Marigold) toward Aedes aegypti. J. Am. Mosq. Control Assoc. 1991, 7, 282-286.

46. Christophers, S.R. Aedes aëgypti (L.) the Yellow Fever Mosquito: Its Life History, Bionomics and Structure; Cambridge University Press: New York, NY, USA, 1960.

47. Neves Filho, R.A.; da Silva, C.A.; da Silva, C.S.; Brustein, V.P.; Dos Santos, F.A.; Alves, L.C.; dos Santos Cavalcanti, M.G.; Srivastava, R.M.; das Gracas Carneiro-Da-Cunha, M. Improved microwave-mediated synthesis of 3-(3-aryl-1,2,4-oxadiazol-5-yl) propionic acids and their larvicidal and fungal growth inhibitory properties. Chem. Pharm. Bull. 2009, 57, 819-825.

48. Warikoo, R.; Kumar, S. Impact of Argemone mexicana extracts on the cidal, morphological, and behavioral response of dengue vector, Aedes aegypti L. (Diptera: Culicidae). Parasitol. Res. 2013, $112,3477-3484$.

49. Watanabe, K.; Umeda, K.; Kurita, Y.; Takayama, C.; Miyakado, M. Two insecticidal monoterpenes, telfairine and aplysiaterpenoid A, from the red alga Plocamium telfairiae: Structure elucidation, biological activity, and molecular topographical consideration by a semiempirical molecular orbital study. Pestic. Biochem. Physiol. 1990, 37, 275-286.

50. Mclaughlin, J.L.; Rogers, L.L.; Anderson, J.E. The use of biological assays to evaluate botanicals. Drug Info. J. 1998, 32, 513-524.

51. Guedes, E.A.C.; de Carvalho, C.M.; Ribeiro Junior, K.A.L.; Lisboa Ribeiro, T.F.; de Barros, L.D.; de Lima, M.R.F.; Prado Moura, F.B.; Goulart Sant'Ana, A.E. Larvicidal activity against Aedes aegypti and molluscicidal activity against Biomphalaria glabrata of Brazilian marine algae. J. Parasitol. Res. 2014, 2014, doi:10.1155/2014/501328. 
52. Sheikh, T.Z.B.; Yong, C.L.; Lian, M.S. In vitro antioxidant activity of the hexane and methanolic extracts of Sargassum baccularia and Cladophora patentiramea. J. Appl. Sci. 2009, 9, 2490-2493.

53. Jones, W.P.; Kinghorn, A.D. Extraction of plant secondary metabolites. In Natural Products Isolation; Sarker, S.D., Latif, Z., Gray, A.I., Eds.; Humana Press: New York, NY, USA, 2005; Volume 20, pp. 323-351.

54. World Health Organization. Guidelines for Laboratory and Field Testing of Mosquito Larvicides Available online: http://www.who.int/whopes/guidelines/en/ (accessed on 29 May 2015).

55. Mulla, M.S.; Singh, N.; Darwazeh, H.A. Delayed mortality and morphogenetic anomalies induced in Culex quinquefasciatus by the microbial control agent Bacillus sphaericus. J. Am. Mosq. Control Assoc. 1991, 7, 412-419.

56. World Health Organization. Report of the WHO Informal Consultation. Test Procedures for Insecticide Resistance Monitoring in Malaria Vectors, Bioefficacy and Persistence of Insecticides on Treated Surfaces. Available online: http://www.who.int/whopes/resistance/en/ (accessed on 20 May 2015).

57. Rajkumar, S.; Jebanesan, A. Oviposition deterrent and skin repellent activities of Solanum trilobatum leaf extract against the malarial vector Anopheles stephensi. J. Insect Sci. 2005, 5, 15.

58. Kramer, W.L.; Mulla, M.S. Oviposition attractants and repellents of mosquitoes: Oviposition responses of Culex mosquitoes to organic infusions. Environ. Entomol. 1979, 8, 1111-1117.

59. Buckingham, J. Dictionary of Natural Products. Available online: http://dnp.chemnetbase.com/ dictionary-search.do?method=view\&id=11136608\&si= (accessed on 20 May 2015).

60. Blunt, J.; Munro, M.H. Dictionary of Marine Natural Products with Cd-Rom; Chapman and Hall/CRC: London, UK, 2008.

61. Zhang, Y.; Han, J.; Mu, J.; Feng, Y.; Gu, X.; Ji, Y. Bioactivity and constituents of several common seaweeds. Chin. Sci. Bull. 2013, 58, 2282-2289.

62. Abbots, W.S. A method of computing the effectiveness of an insecticide. J. Econ. Entomol. 1925, $18,265-267$.

Sample Availability: Samples of the extracts are available from the authors.

(C) 2015 by the authors; licensee MDPI, Basel, Switzerland. This article is an open access article distributed under the terms and conditions of the Creative Commons Attribution license (http://creativecommons.org/licenses/by/4.0/). 